\title{
Fort Des Moines (1834-1837): An Archaeological Test
}

Marshall McKusick

THE LANDS WEST of the Mississippi opened to settlers in the year following the Black Hawk Purchase of 1832. The area which subsequently became Iowa was administratively governed as part of the Michigan Territory from 1834-1836, Wisconsin Territory during 1836-1838, and as the Iowa Territory from 1838-1846, at which time statehood was approved. To protect the western frontier of the Michigan Territory, the War Department decided to establish a new military post on the west side of the Mississippi as a center for military operations and explorations. The military post was named Fort Des Moines because of its position at the head of the rapids on the Mississippi River which began just below the present day townsites of Nauvoo, Illinois, and Montrose, Iowa. The rapids continued south twelve miles to what is now Keokuk, Iowa, above the junction of the Des Moines River into the Mississippi. The fort site at the rapids was strategically significant as a boat landing, and travelers usually stopped before entering the dangerous rapids, or upon safely navigating them upstream. The landing was at the head of a trail which paralleled the rapids on the west or Iowa side. During the American Revolutionary War period a small outpost manned by French Canadians was situated at or near the landing to keep British traders from going west up the Des Moines River. Some years later in 1799 the landing was part of the Spanish land grant, given to Louis Honore Tesson. It subsequently had other owners. At the time Fort Des Moines was established in 1834 there were some white settlers in 
the area known as Cut Nose Village-and a few Indians may have been in temporary residence. ${ }^{1}$

Lieutenant George H. Crossman began construction of the fort in the fall of 1834, and was joined by Lt. Colonel Stephen W. Kearney, with a full garrison. The soldiers were the 1st Dragoons, companies B, H, and I, and numbered about 150 men.Dragoons were mounted on horseback for mobility, but were trained to fight on foot once a military action commenced. They were intermediate between infantry and cavalry, cavalry being trained to charge and fight from horseback. The choice of a building-site by a steamboat landing was made in order to facilitate supplying the garrison. No stockade was built because there was no threat of Indian attack. The post was a headquarters for patrols and expeditions into the largely unexplored Indian country to the west.

Despite ease of supply, the fort location was low and unhealthy, and both officers and men were frequently sick. One English visitor who stopped at the fort made the following observation:

[the location was] . . . chosen with singularly bad judgment; it is low, unhealthy, and quite unimportant from a military point of view ... I landed ... only for a few minutes, and had but just time to remark the pale and sickly countenances of such soldiers as were loitering about the beach; indeed, I was told by a young man who was sutler [storekeeper] at this post, that when he had left it a few weeks before, there was only one officer on duty out of seven or eight, who were stationed there. The number of desertions from this post was said to be greater than from any other in the United States . . . If we take into consideration the facilities of escape in a steam-boat, by which a deserter may place himself in a few days in the recesses of Canada, Texas, or the mines, and at the same time bear in mind the feebleness with which the American military laws and customs follow or punish deserters, we shall only wonder that the ranks can be kept as full as they are ...2

\section{Lieutenant Crossman's Map of Fort Des Moines}

A Lee County history contains a brief description by a pioneer settler of the fort barracks as having a sleeping room on each end

'Jacob Van der Zee, "Forts in the Iowa Country," Iowa Journal of History and Politics (The State Historical Society of Iowa, 1914) 12:178-182; History of Lee County, Iowa (Chicago: Western Historical Company, 1879). This fort has been called Fort Des Moines No. 1, distinguishing it from two later forts of the same name within the present boundaries of the City of Des Moines. The 1834 correspondence refers to the post as Camp Des Moines, and that name appears on the Crossman map. The term fort became official the following year.

${ }^{2}$ Van der Zee, pp. 180-181, quoting Charles Murray, Travels in North America, Vol. 2. 
and two mess rooms around a central chimney. Actually, the barracks were substantially larger. A 1834 plan by Lieutenant Crossman shows details of the fort design: two of the buildings from the plan are shown here as examples (Figure 1). ${ }^{3}$ Since there was no stockade, the living quarters of both officers and men formed an open square around the parade ground, 400 feet across with the well near the center (Figure 2). The parade ground sloped gently down towards the Mississippi River, so the long buildings on the sides of the square were built in two stages, one set slightly below the other. The building on the southeast side of the parade ground was about 160 feet by 20 feet, with 4 chimneys and 8 rooms. It was used for officers' quarters, hospital, carpenter's shop and guard house. The similar-sized building across the square provided additional officer's quarters. The three enlisted men's barracks at the upper end of the parade ground were similar in plan. Each one was a long, low, single story building with a dormer roof and loft. The ground plan of Company I barracks shows it was 127 feet by 20 feet in size, with a store room, orderly room, a mess and kitchen on either side of the central double fireplace, and two bunk rooms. Two small chimneys indicate the location of heating stoves. The quarters of the commanding officer, Colonel Kearney, were near the river. It was a large, 40-footsquare building, with a central hall, and four large rooms, with probably two more rooms under the dormer roof. The stables are shown as single story sheds, grouped around two squares, a plan apparently not finally adopted.

\section{Robert E. Lee's Map of the Des Moines Rapids}

Robert E. Lee, who later commanded the Confederate Army in Virginia, was a lieutenant in the 1830s, attached to the U.S. Army Corps of Engineers. The turbulent, shallow, twelve-mile Des Moines Rapids was a major navigational hazard for boats on the Mississippi, and the Army Corps of Engineers assigned Lieutenant Lee the task of taking soundings and mapping the channel. Lee's map, dated 1837, included the location of the Fort Des Moines barracks, stables, and other buildings, and shows the location of the fort well in the center of the parade ground surIsland.

${ }^{3}$ Photostat previously unpublished, U.S. Army Corps of Engineers, Rock 
rounded by the barracks and smaller buildings. The illustration (Figure 3) is part of a larger drawing of the rapids at a scale of five inches to one mile, the channel depths being given in feet and inches, the fort buildings not being specificially identified. This drawing has not to my knowledge been previously published, and the illustration is from the October 6, 1866 recopy of the original

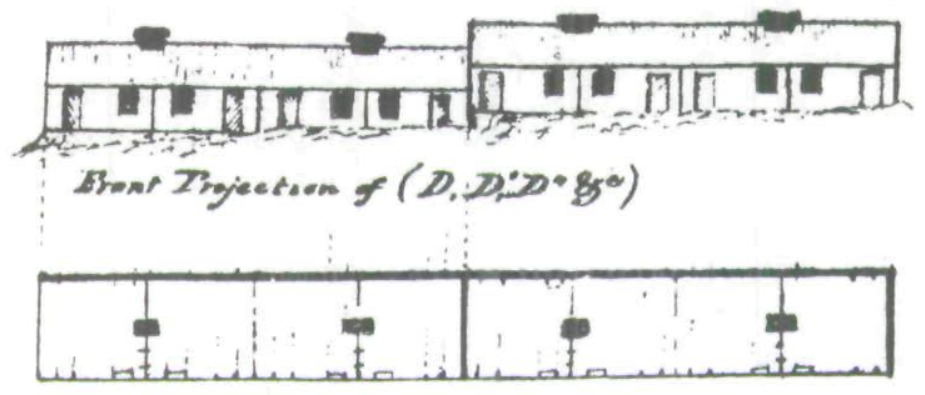

BARRACKS, SOUTHEAST PARADE GROUND

(Guard House, Carpenter, Hospital, and officer Quarters)
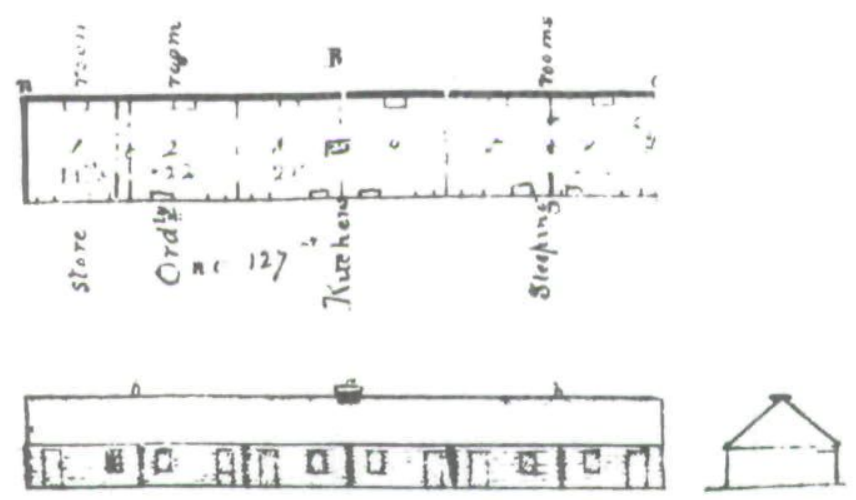

BARRACKS, SOUTHWEST PARADE GROUND (Enlisted Men, Company I, 1st U. S. Dragoons)

Figure 1: Fort Des moines barracks. Reproduced from parts of the Crossman map of 1834. Captions added for identification. 


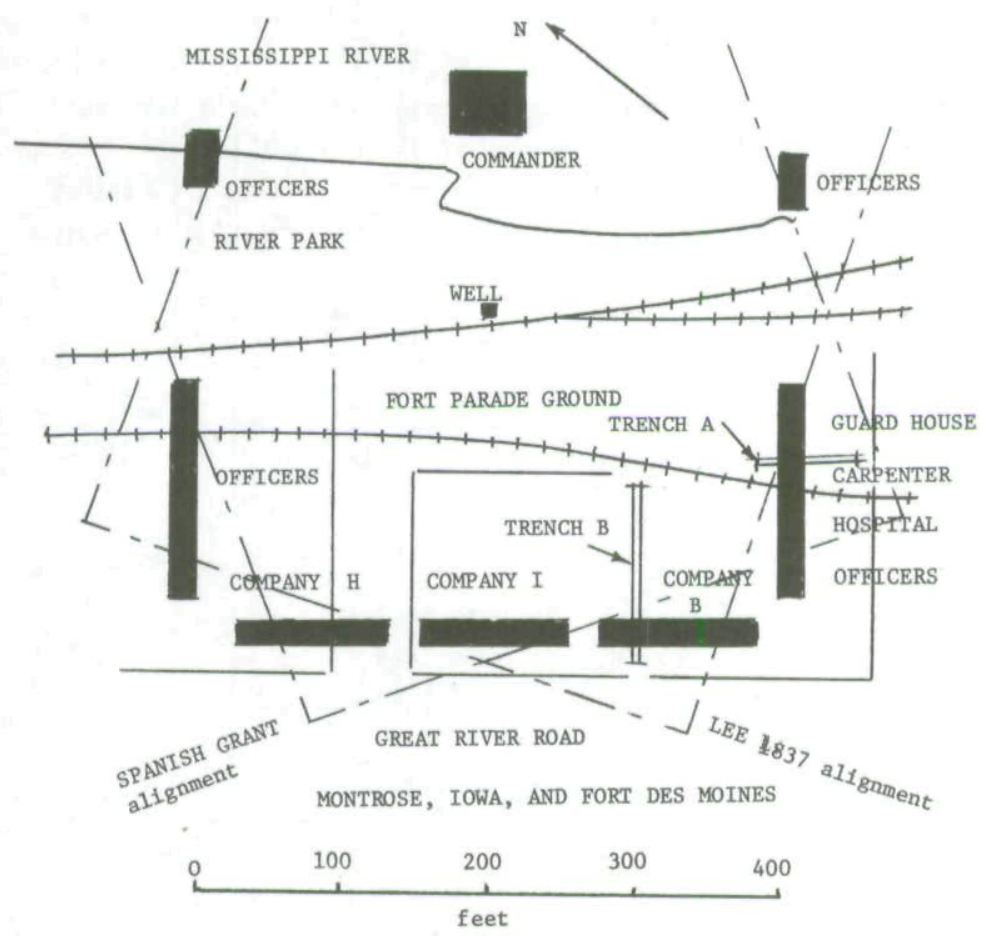

Figure 2: Street plan of Montrose, Iowa showing three possible alignments of Fort Des Moines and the archaeological testing.

Lee map by the U.S. Army Corps of Engineers. ${ }^{4}$ The major difference between the Lee and Crossman maps lies in the stable plan. Lee shows them to be three long sheds, one for each dragoon company, instead of hollow squares, and since his plan is almost three years after Crossman's it is probably correct.

\section{Traditional History}

The territory was increasingly being settled and the dragoons were garrisoned further west, the fort being abandoned in 1837 . Several early settlers and a former soldier continued to live in the area and some stories about the fort were incorporated in various Lee County histories with varying degrees of reliability. The set-

${ }^{4}$ Photocopy provided by U.S. Army Corps of Engineers, Rock Island. The north arrow appears elsewhere on the plan, and is added to the illustration. 
tlement grew up around the fort, an officer reporting, "A town has been laid off at this place, and lots have been sold, which takes in part of our garrison." The settler, David Kilbourne, named the townsite Montrose and laid it out south of the fort in the former Tesson orchard, but it apparently extended into the fort. It turned out he did not have title to the orchard and another

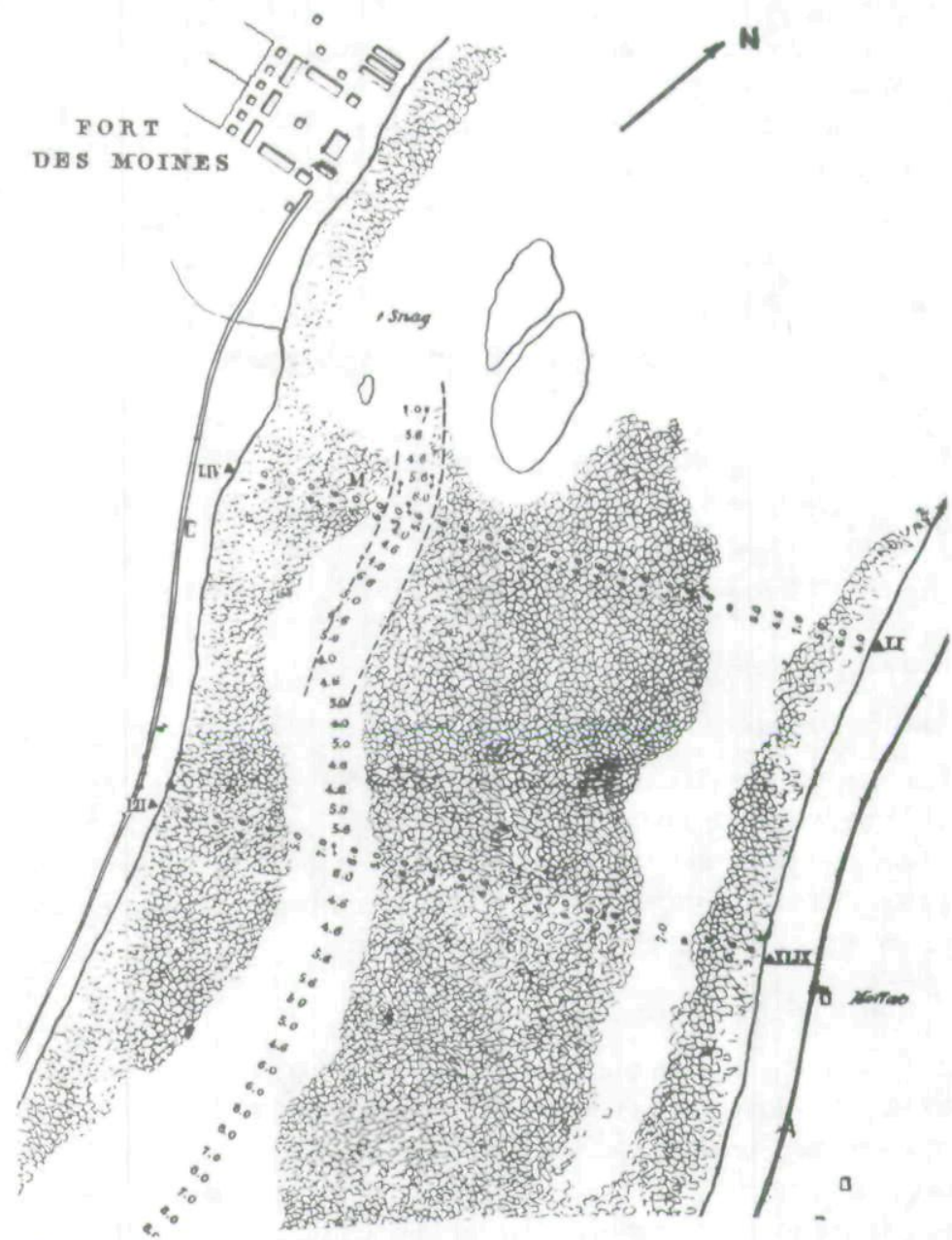

- Figure 3: The head of the Des Moines Rapids and Fort Des Moines on the Mississippi. Section reproduced from the R. E. Lee plan of 1837. 
man named Riddick successfully won his own claim in court. The name for the town remained Montrose but the townsite was replatted. The commodious quarters used by Colonel Kearney became a hotel named River House but the fate of the other buildings is unknown. The smaller log cabins were probably reused or moved, and the long barracks of logs were probably dismantled by settlers for the usable lumber and logs. It is said the stables were originally framed in St. Louis, shipped to the fort, and put together on the ground. Built of lumber rather than logs, they also disappeared. The streets of Montrose today parallel the river bank, and seem aligned with the older fort plans. ${ }^{5}$

There is a tradition, not mentioned in the county histories, that the fort well was in the town and eventually it was marked by a small monument and bronze plaque. Given the well location and street alignment I decided to attempt the relocation of Fort Des Moines.

The river bank in the Montrose area changed a great deal after Lieutenant Lee mapped the river in 1837. A canal through the rapids completed in the 1870 s became obsolete and in 1913 the Keokuk Lock and Dam created a substantial backwater reservoir, flooding the rapids and innundating the low shore line upstream. The Lee County Engineer redrew one line of the original land survey for me, in the fort area, confirming that the river side of the fort site is now under water.

The fort well location was confused when a small riverside park was established nearby. Without regard to historical accuracy, the bronze plaque identifying the fort well had been taken down and reset by the park pump. The original concrete monument is still in place by the railroad and was used as a base point on the map. Two students working with me made a plat map of the town of Montrose adjacent to the well. Then the barracks and well were redrawn to the same scale from the Crossman map and projected over the existing buildings, railroad tracks, and streets. The map (Figure 2) assumes that the present alignment of Montrose streets followed the fort plan. True north on Figure 2 is based on a projection from the U.S.G.S. Nauvoo quadrangle. When true north is projected to this alignment from Lee's map it will be

${ }^{5}$ History of Lee County. Iowa; Portrait and Biographical Album of Lee County, Iowa (Chapman Brothers, 1887); Story of Lee County (Chicago: S. J, Clarke Publishing Co., 1914). 
noted that his north is 20 degrees west. Magnetic deviation on both the maps is comparable. Despite this evidence against the alignment correlation there is supporting evidence that Lee's north may be in error. There is another U.S. Army Corps of Engineer's map of the Des Moines Rapids by Gen. J. H. Wilson dated March 26, 1867. The Wilson Map has comparable topography to Lee, but true north corresponds to the north on our alignment. Unfortunately the Wilson map does not show the Montrose plat. ${ }^{6}$ The Crossman fort plan unfortunately lacks a north arrow.

The map (Figure 2) shows three possible alignments of the fort with the existing street plan: (1) the correlation of the fort with Montrose streets, (2) the correlation with Lee's map, and (3) the correlation with Spanish land grant boundaries. The first two possibilities have been described. In explanation of the third alternative, the Spanish land grant boundaries ran directly back from the alignment of the river, NE by SW, encompassing a square league and later reduced to a square mile. The land grant is still on maps today because it was not included in the townshiprange land survey system, the grant being a pre-existing but approved surveyed tract. A narrow country lane still parallels the 1799 alignment on two sides. It is quite possible that river property was laid out to conform to the original grant, since the grant itself paralleled the river. If this is true the streets have shifted 20 degrees, but in a line 40 degrees from the Lee alternative.

\section{Archaeological Testing of the Map}

My investigations at Fort Madison (1808-1813) in 1965 discovered limestone rubble foundations and cellars under the major buildings. In 1966 I made a thorough study of the foundations at Fort Atkinson and conducted archaeological investigations. ${ }^{7}$ The success of these investigations suggested that Fort Des Moines might, too, have significant underground remains. The preliminary mapping was carried out in the spring, and I made an archaeological test on July 19, 1966. I chose two unpaved alleys

${ }^{6}$ Wilson map photostat, U.S. Army Corps of Engineers, Rock Island.

'Marshall McKusick and David Archie, "A Tale of Two Forts: Fort Madison and Fort Atkinson," The Iowan Magazine (1966) 15:10-15, 50-51; Fort Madison Archaeology, $16 \mathrm{~mm}$, color, sound, 15 minutes, (Film 7, Ancient Iowa Series) University of Iowa Audiovisual Center, lowa City (1973). 
crossing the suspected barracks location, hired a backhoe for exploratory work, and had a crew of students in attendance. On the SE-NW line (Figure 2, trench A) a 65-foot-long, two-foot-wide backhoe trench was cleared. Black humus and disturbed soil occurred to a depth which averaged two feet. This was partly landfill brought in to build up the original ground surface. The fill overlaid undisturbed reddish colored clay. The trench was four-feetdeep, extending two feet into the apparently undisturbed clay. No construction evidence or diagnostic features were encountered in trench A. On the SW-NE line (Figure 2, trench B) the two-footwide trench began at the building line, inside the sidewalk which parallels the Great River Road, a continuation of Lee County road X-28. Trench B ran the length of the alley to the railroad tracks but encountered no evidence of either a cellar or stone foundation. The alley was covered by four inches of humus overlying successively two inches of alley gravel, about 20 inches of mixed humus and disturbed soil, and underlaid by two feet of apparently undisturbed reddish clay. The stratigraphy of both trenches was similar. A recent privy occurred in the trench just $\mathrm{NE}$ of the plotted barracks. It was identified by interested spectators as formerly in use by employees of the adjacent locker plant, and we did not investigate it further. Continuing NE 63 feet from the sidewalk, we encountered a foundation of limestone rubble laid without mortar which was part of an earlier privy which we did not completely excavate. Regardless of which of the three map correlations is used, this privy had been built in the former parade ground, and was built after the fort was abandoned. An emergency highway salvage excavation of archaeological remains at Jolleyville Hill, near Wever, Highway 61, made it necessary to shift my crew. The Fort Des Moines backhoe excavation was refilled without obtaining positive results.

There are several possibilities which may explain the lack of archaeological evidence for the Fort Des Moines barracks: (1) The existing streets may not parallel the old fort; (2) The traditional location of the fort well may be in error; (3) The map projection may be in error for other, but unknown reasons; and (4) The barracks, built for a temporary military occupation, may have lacked the limestone rubble foundations found at other U.S. Army forts in Iowa. It was, for example, a common frontier practice to rest log buildings on upright foundation posts, the posts 
being buried so that the upper end was at ground level. ${ }^{8}$

The presence of the modern town and miscellaneous construction activities complicate the search for the fort location. I remain convinced that there are significant artifacts and fort ruins still preserved in the vicinity of the fort well. The barracks may lie on the alignment projected by Lee's map, and if this is the case the exploratory trenches were in the parade ground, and did not cross the barracks. The other two possibilities have been tested. I hope my notes on the search for Fort Des Moines spurs someone to make a full historical study, based upon the unpublished correspondence in the National Archives. The map should be consulted if construction is undertaken in the vicinity of the traditional fort well.

${ }^{8}$ The Civil War period Northern Border Brigade forts had substantial log buildings of one and two stories, resting on upright corner posts rather than stone foundations. Marshall McKusick, The Iowa Northern Border Brigade, State Archaeologist Report 9, Iowa City, 1975. 
Copyright of Annals of Iowa is the property of State of Iowa, by \& through the State Historical Society of Iowa and its content may not be copied or emailed to multiple sites or posted to a listserv without the copyright holder's express written permission. However, users may print, download, or email articles for individual use. 